\title{
Association between a urinary biomarker for exposure to PAH and blood level of the acute phase protein serum amyloid $A$ in coke oven workers
}

Niels Hadrup ${ }^{1}$ DD, Danuta Mielżyńska-Švach ${ }^{2,3}$, Agnieszka Kozłowska ${ }^{3}$, Manuela Campisi ${ }^{4}$, Sofia Pavanello $^{4}$ and Ulla Vogel $\left.\right|^{*}$

\begin{abstract}
Background: Coke oven workers are exposed to both free and particle bound PAH. Through this exposure, the workers may be at increased risk of cardiovascular diseases. Systemic levels of acute phase response proteins have been linked to cardiovascular disease in epidemiological studies, suggesting it as a marker of these conditions. The aim of this study was to assess whether there was association between PAH exposure and the blood level of the acute phase inflammatory response marker serum amyloid A (SAA) in coke oven workers.

Methods: A total of 87 male Polish coke oven workers from two different plants comprised the study population. Exposure was assessed by means of the individual post-shift urinary excretion of 1-hydroxypyrene, as internal dose of short-term PAH exposure, and by anti-benzo[a]pyrene diolepoxide (anti-B[a]PDE)-DNA), as a biomarker of long-term PAH exposure. Blood levels of acute phase proteins SAA and CRP were measured by immunoassay. C-reactive protein (CRP) levels were included to adjust for baseline levels of SAA.

Results: Multiple linear regression showed that the major determinants of increased SAA levels were urinary 1 -hydroxypyrene (beta $=0.56, p=0.030$ ) and serum CRP levels (beta $=7.08 ; p<0.0001$ ) whereas anti-B[a]PDE-DNA, the GSTM1 detoxifying genotype, diet, and smoking were not associated with SAA levels.

Conclusions: Urinary 1-hydroxypyrene as biomarker of short-term PAH exposure and serum levels of CRP were predictive of serum levels of SAA in coke oven workers. Our data suggest that exposure of coke oven workers to PAH can lead to increased systemic acute response and therefore potentially increased risk of cardiovascular disease.
\end{abstract}

Keywords: Acute phase response, Particles, Pulmonary, Toxicity, Serum amyloid A

\section{Background}

Coke oven workers are exposed to polluted air. This polluted air consists of a particle and a gaseous phase both containing a long range of different substances including polycyclic aromatic hydrocarbons (PAH). The exposure of coke oven workers to polluted air likely poses a risk to their health. Air pollution has previously been associated to such diseases as cancer and cardiovascular diseases [1,

\footnotetext{
* Correspondence: ubv@nrcwe.dk

${ }^{1}$ National Research Centre for the Working Environment, DK-2100

Copenhagen, Denmark

Full list of author information is available at the end of the article
}

2]. Exposure to PAH in the American population has been reported to be associated to cardiovascular disease $[3,4]$ and to peripheral arterial disease [5] in addition, PAH was found to contribute to the increased carotid intima-media thickness - an atherosclerosis marker - in taxi drivers [6]. Pulmonary exposure to particulate air pollution has been associated with increased risk of cardiovascular morbidity and mortality [7-9].

The acute phase response is activated during inflammation. The blood levels of acute phase proteins Serum amyloid-A (SAA) and C-reactive protein (CRP) are suggested to be predictive of cardiovascular disease risk in

(c) The Author(s). 2019 Open Access This article is distributed under the terms of the Creative Commons Attribution 4.0 International License (http://creativecommons.org/licenses/by/4.0/), which permits unrestricted use, distribution, and 
humans [10]. SAA is causally implicated in atherosclerosis by promoting formation of foam cells and by increased formation of plaques in aorta [11-19], whereas the function of CRP is less clear [20]. PAH exposure has been reported to be associated with increased CRP levels in humans [21]; and it has been hypothesised that particle exposure may cause cardiovascular disease through particle-mediated acute phase response and lung inflammation [22, 23]. In mice, airway exposure to insoluble particles induces a dose-dependent pulmonary acute phase response, a complex systemic response characterised by alterations in blood levels of Serum Amyloid A (SAA) [23-32]. Recently, inhalation of $\mathrm{ZnO}$ nanoparticles was shown to induce dose-dependent acute phase response in terms of SAA and CRP blood levels in human volunteers [33]. $\mathrm{ZnO}$ dissolves when phagocytized by macrophages. This has provided important evidence for particle-induced acute phase response in humans [34], but evidence for induction of acute phase response by insoluble particles is still needed.

In this work we hypothesised that the acute phase response was activated after exposure to coke oven emissions. To investigate this, we needed an appropriate biomarker of exposure. We assessed PAH as a marker of airway pollution because: 1) PAH is an important constituent of coke oven emissions [35-37]; and 2) it is in itself known to be toxic - as described above. In the current work we assessed short (hours to days) and long-term (months) PAH exposure by measuring urinary excretion of the pyrene metabolite 1-hydroxypyrene, a commonly used marker of the internal dose of $\mathrm{PAH}$ [37-42] and DNA adduct levels of benzo[a]pyrene diolepoxide (anti-B[a]PDE)-DNA) adduct in blood cells, a marker of the effective long-term PAH exposure.

Thus to investigate the association between the exposure to coke oven air pollution and the acute phase response, we measured the blood concentration of SAA and conducted multiple linear regression using the PAH biomarkers 1-hydroxypyrene and anti-B[a]PDE)-DNA as well as the GSTM1 genotype, smoking, charcoaled meat consumption, and C-reactive protein (CRP) levels as explanatory variables. The GSTM1 null genotype was included as it has previously been shown to be a risk factor for anti-B[a]PDE-DNA adduct formation [43, 44]. Smoking and charcoaled meat consumption were included in the analysis to adjust for PAH exposure through these sources. C-reactive protein (CRP) levels were included to adjust for baseline levels of SAA [45].

\section{Methods}

\section{Workers included in the investigation}

Eighty-seven male Polish coke oven workers were enrolled from two plants as described previously [43, 46]. For each subject, data regarding age, tobacco smoking and charcoal-broiled meat consumption, occupational and environmental exposure to $\mathrm{PAH}$, personal behaviour and the possible use of coal tar-based ointment, shampoo or soap, were collected by means of a questionnaire administered by trained interviewers. The characteristics of the study group are summarised in Table 1. All participants gave their informed consent. All information regarding participants was rendered anonymous after collection of data, urine and blood samples. The study design was reviewed and approved by the appropriate Ethics Committee of the Institute of Occupational Medicine and Environmental Health in Sosnowiec (Poland).

\section{Sample collection}

Urine $(50 \mathrm{~mL})$ and blood $(20 \mathrm{~mL})$ samples were collected from all subjects between March and June 2002. Samples from workers were collected at the end of the work-shift, after at least 3 consecutive days of work. Within $4 \mathrm{~h}$ of blood collection, mononuclear lymphocyte plus monocyte fractions (LMF) were isolated in Ficoll separating solution (Seromed, Berlin, Germany), as previously described [47]. LMF, serum and urine samples were kept frozen at $-80^{\circ} \mathrm{C}$ until their transport to the Department of Environmental Medicine and Public Health in Padova (Italy) for further analysis.

\section{Determination of 1-hydroxypyrene, anti-B[a]PDE-DNA adducts, and GSTM1 genotypes}

$\mathrm{PAH}$ exposure (occupational, environmental and dietary sources) was evaluated by means of the post-shift urinary excretion of 1-hydroxypyrene, normalised to creatinine

Table 1 General characteristics of enrolled coke oven workers

\begin{tabular}{|c|c|}
\hline Variable [unit] & \\
\hline \multicolumn{2}{|l|}{ Number of subject [N (\%)] } \\
\hline Female & $0(0)$ \\
\hline Male & $87(100)$ \\
\hline Age in years [mean $\pm S D$, range] & $\begin{array}{l}39 \pm 10(22- \\
55)\end{array}$ \\
\hline \multicolumn{2}{|l|}{ GSTM1 genotypes [N (\%)] } \\
\hline Active & $58(66)$ \\
\hline${ }^{*} 0 /{ }^{*} 0$ & $29(33)$ \\
\hline \multicolumn{2}{|l|}{ Current smoking habits ${ }^{\mathrm{a}}[\mathrm{N}(\%)]$} \\
\hline Non-smokers & $34(39)$ \\
\hline Smokers & $53(61)$ \\
\hline $\begin{array}{l}\text { Level of smoking in smokers (cigarettes/day) [mean } \pm S D \text {, } \\
\text { range] }\end{array}$ & $23 \pm 7(8-40)$ \\
\hline \multicolumn{2}{|l|}{$\operatorname{Diet}^{\mathrm{b}}[\mathrm{N}(\%)]$} \\
\hline No $\geq$ once a week & $22(25)$ \\
\hline No<once a week & $65(75)$ \\
\hline
\end{tabular}

${ }^{a}$ Smokers are defined as current smokers

${ }^{\mathrm{b}}$ Numbers of subjects with charcoaled meat consumption $\geq$ or $<$ once a week 
( $\mu$ mol1-hydroxypyrene /mol creatinine) and anti-B[a]PD E-DNA adduct levels in the blood fraction consisting of both mononuclear lymphocytes and monocytes. 1-hydroxypyrene and anti-B[a]PDE-DNA adducts were previously reported [43]. GSTM1 genotyping data were previously published [43]. Briefly, 1-hydroxypyrene was determined in urine samples as formerly described [47], following the original method of Jongeneelen [48]. The levels were expressed per moles of urinary creatinine, determined according to the Boehringer-Mannheim colorimetric test, based on the reaction of creatinine with picrate in alkaline medium. As proposed by Jongeneelen [48], we considered the urinary 1-hydroxypyrene value of $2.28 \mu \mathrm{mol} / \mathrm{mol}$ creatinine as the biological exposure index (BEI). It was calculated that a concentration of $2.28 \mu \mathrm{mol} 1$ hydroxypyrene/mol creatinine after a 3-day working period in the urine of coke oven workers equals the airborne threshold limit value (TLV) of coal tar pitch volatiles (CTPV), i.e. $0.2 \mathrm{mg} / \mathrm{m}^{3}$ of 'benzene-soluble matter' [49]. After DNA extraction, anti-B[a]PDE-DNA adducts were detected by HPLC/fluorescence analysis of anti-BaP tetrols (tetrol I-1, see abbreviations) released upon acid hydrolysis of DNA samples. HPLC/fluorescence analysis of anti-B[a]PDE-DNA adducts was carried out as previously described [50], and is identical to that reported by [51] with some modifications mainly regarding the entire automation of the HPLC analysis. Briefly, a total amount of at least $100 \mu \mathrm{g}$ of DNA from LMF was used for each analysis. Many precautions were taken to avoid the presence of fluorescent contaminates: the absence of any fluorescent material in the purified $\mathrm{HCl}$ was checked by HPLC; tubes, HPLC syringes and other equipment were washed many times with HPLC purity-grade methanol, and a blank injection was performed before each sample was subjected to HPLC analysis. The fluorescence excitation wavelength was set at $344 \mathrm{~nm}$ and the emission wavelength at $398 \mathrm{~nm}$. The level of B[a]P-tetrol-I-1 was determined by comparison with a standard curve generated from the fluorescence areas of an authentic B[a]Ptetrol-I-1 standard (purchased from NCI Chemical Carcinogen Reference Standard Repository, Kansas City, MO, USA), analysed prior to and immediately following the analysis of each set of samples. Calibration curves were made with DNA from calf thymus, alone (background) and spiked with $2,4,10,20,40$ and $80 \mathrm{pg}$ of B[a]P-tetrolI-1. These standard solutions were then treated in the same way as the tested samples (hydrolysed in $0.1 \mathrm{~N} \mathrm{HCl}$ at $90^{\circ} \mathrm{C}$ for $4 \mathrm{~h}$ ). The minimum correlation coefficient was 0.9998 and the mean coefficient of variation for analyses repeated on different days was $10 \%$. The detection threshold of B[a]P-tetrol-I-1 was $1 \mathrm{pg}$ (signal/noise $>3$ ) so that, in the present study, with $100 \mu \mathrm{g}$ DNA, this assay can measure 1 adduct $/ 10^{8}$ nucleotides $(1 \mathrm{fmol} / \mu \mathrm{g}$ DNA $=30$ adducts $/ 10^{8}$ nucleotides). A multiplex polymerase chain reaction (PCR) method was used to detect the presence or absence of the GSTM1 gene, according to the protocol formerly described [52]. This PCR method applied, in the same amplification mixture, GSTM1-specific primer pairs and a primer pair for $\beta$-globin, as an internal positive PCR control. $\beta$-Globin (285 bp) and GSTM1 (215 bp) amplification products were resolved in an ethidium bromidestained 2\% agarose gel. The absence of the GSTM1-specific fragment indicated the corresponding null genotype $(" 0 / * 0)$, the presence of the fragment correspond with the " $1 / * 1$ and "0/"1 genotypes, whereas the $\beta$-globin-specific fragment confirmed the presence of amplifiable DNA in the reaction mixture.

\section{Determination of acute phase proteins}

Upon blood sampling SAA and CRP levels were determined by Enzyme-linked Immunosorbent assay (ELISA) as previously described [53]. In brief, SAA was determined in serum samples with kit product number KHA0011 (Invitrogen CA, USA), as specified by the manufacturer. The reported detection limit (LOD) was $4 \mathrm{ng} / \mathrm{mL}$. Recombinant human SAA1 supplied with the kit was included as positive control in all measurement runs. CRP was determined with a kit from IBL International GMBH (prod number EU59151, Hamburg, Germany). The LOD was $20 \mathrm{ng} / \mathrm{mL}$. All SAA and CRP measurements were above LOD. Human CRP was used as positive control in all measurement runs (code 85/ 506, NIBSC).

\section{Statistics}

Linear multiple regression analyses were done using the BMDP software package [54]. The analysis comprised, SAA as a dependent variable with the following explanatory variables: 1 . Urinary excretion of 1-hydroxypyrene, 2. Anti-B[a]PDE-DNA-adducts, 3. GSTM1 status, 4. CRP. 5. Smoking habits, 6. Diet habits. Smoking was included as 1 or 0 , based on whether the worker was current smoker or a non-smoker. Diet was included as 1 or 0 based on whether charcoaled meat consumption was more or less than once per week, respectively. $P$ values were calculated for each explanatory variable. The slope $(\beta)$ as well as the test statistics $(T=\beta /$ standard deviation of $\beta$ ) were reported. The F-test was calculated to determine the overall significance of the test. In addition the above tests were done in the absence of CRP as an explanatory variable. And CRP was tested as dependent variable with explanatory variables 1-hydroxypyrene, 2 . Anti-B[a]PDE-DNA-adducts, 3. GSTM1 status, 4. SAA. 5. Smoking habits, 6. Diet habits. And this latter test was also done excluding SAA as an explanatory variable.

The serum levels of SAA and CRP were also tested for changes between 3 ranges of the urine level of 1-hydroxypyrene $(\mathrm{I} \leq 2.30 / \mu \mathrm{moles} / \mathrm{mole}$ creatinine; $\mathrm{II}>2.30 \leq$ 
7.04, and III > 7.04). This was done by the Mann-Whitney $U$ test.

\section{Results}

As reported previously [43], coke-oven workers were heavily exposed to $\mathrm{PAH}$, as the urinary 1-hydroxypyrene concentrations in 70,90 and $85 \%$ of the workers exceeded $2.28 \mu \mathrm{mol} / \mathrm{mol}$ creatinine, $1.0 \mu \mathrm{mol} / \mathrm{mol}$ creatinine and $2.5 \mu \mathrm{g} / \mathrm{L}$, respectively. The two first values are the biological exposure index (BEI) proposed by Jongeneelen in 1992 and 2014 [38, 39]. The third value is the BEI proposed by ACGIH in 2016 [55]. The 2.28 value corresponds to the post-shift excretion value after an environmental exposure to the airborne threshold limit value of coal tar pitch volatiles (i.e., $0.2 \mathrm{mg} / \mathrm{m}^{3}$ of "benzene soluble matter," ACGIH). For this value a relative risk (RR) of 1.3 for lung cancer has been estimated for coke oven workers [38]. The BEI of $2.5 \mu \mathrm{g} / \mathrm{L}$ proposed by ACGIH in 2016 [55] is adjusted for the pyrene to benzo(a)pyrene ratio of the PAH mixture to which workers are exposed. This value corresponds to $1.3 \mu \mathrm{mol} / \mathrm{mol}$ creatinine at the usual urinary creatinine level of $1 \mathrm{~g} / \mathrm{L}$ and is therefore very similar to a value of $1.4 \mu \mathrm{mol} / \mathrm{mol}$ creatinine proposed by Buchet et al.; based on the minimum level of urinary 1-hydroxypyrene associated with increased frequency of sister chromatid exchanges in peripheral blood lymphocytes of nonsmokers [56]. Moreover, anti-B[a]PDE-DNA adducts were detected in the blood of almost all of the coke oven workers $(98 \%, n=85)$.

SAA and CRP levels correlated closely $\left(R^{2}=0.74\right)$ but varied greatly between individuals (Table 2 ). As baseline levels vary significantly between individuals due to biosynthesis in adipose tissue $[45,57,58]$, CRP levels were used as a biomarker for baseline levels of acute phase response as previously described [45]. Linear multiple regression (Table 3) showed that the major determinants of SAA levels were urinary 1-hydroxypyrene (beta $=0.56, p=0.03$ ) and CRP serum levels (beta $=7.08 ; p<0.0001$ ) whereas anti-B[a]PDE-DNA adducts, the GSTM1 genotype, diet and smoking did not predict SAA levels. When CRP was excluded from the analysis there was no effect of 1-hydroxypyrene, but an effect of GSTM1 $(p=0.03)$ (Additional file 1: Table S1). The determinants of CRP levels were urinary 1-hydroxypyrene urinary 1-hydroxypyrene (beta $=$ - 0.08, $p=0.01$ ) and CRP serum levels (beta $=0.003 ; p<$ 0.0001 ) whereas anti-B[a]PDE-DNA adducts, the GSTM1 genotype, diet and smoking did not predict CRP levels (Table 4). When SAA was excluded from the analysis there was no effect of any of the explanatory variables (Additional file 2: Table S2). Concerning the potential relation of SAA, CRP, and 1-hydroxypyrene when not tested by multiple linear regression, the serum levels of SAA and CRP were not statistically related to the three categories of 1-hydroxypyrene in urine, when tested by the MannWhitney $U$ test (Table 5).

\section{Discussion}

In the present study, we wanted to assess the potential association between coke oven occupational exposure to $\mathrm{PAH}$ and a marker of systemic acute phase response. Short-term exposure was assessed by urinary 1-hydroxypyrene excretion whereas long-term exposure was assessed by anti-B[a]PDE-DNA adduct levels in blood cells.

By multiple linear regression, urinary 1-hydroxypyrene was positively associated with SAA levels with a $p$-value of 0.03 and a slope of 0.6. At the same time, CRP was also associated with SAA with a $p$-value of less than 0.0001 and a slope of 7.1. This suggests that there is a link between PAH exposure and acute phase reaction induction in these workers, when adjusting for the association of CRP. CRP was inter-related to hydroxypyrene as the slope of 1-hydroxypyrene is different in the presence and absence of CRP in the analysis (Table 4 and Additional file 1: Table S1). Therefore it is reasonable to include CRP as an explanatory variable when analysing the association between PAH exposure and 1-hydroxypyrene to adjust for its variation. In addition, in a study on Finnish children and young adults randomly chosen from the national population registers of a number of Finnish cities, it was found that SAA correlated with CRP, waist circumference, and leptin and with different additional factors specifically in men and women [45]. Based on this, the inclusion of CRP as an explanatory variable adjusts for inter-individual variation in the baseline levels of SAA. As a side note, the serum levels of SAA and CRP were not statistically related to the three

Table 2 Levels of biomarkers of exposure and effect

\begin{tabular}{|c|c|c|c|c|}
\hline Biomarkers/assay [unit] & Median & Mean \pm SD & Range & $\mathrm{N}(\%)$ above the limit value \\
\hline 1-hydroxypyrene urine concentration $(\mu \mathrm{mol} / \mathrm{mol} \text { creatinine) })^{a}$ & 4.31 & $6.81 \pm 7.40$ & $0.25-31.4$ & $60(70)$ \\
\hline Anti-B[a]PDE-DNA (adducts/ $10^{8}$ nucleotides) ${ }^{\mathrm{b}}$ & 2.89 & $4.03 \pm 3.65$ & $1.00-27.4$ & $85(98)$ \\
\hline $\mathrm{SAA}(\mu \mathrm{g} / \mathrm{mL})$ & 3.07 & $34.18 \pm 180.14$ & $0.36-1200$ & \\
\hline $\operatorname{CRP}(\mu \mathrm{g} / \mathrm{mL})$ & 0.36 & $0.95 \pm 2.73$ & $0.4-24.3$ & \\
\hline
\end{tabular}

${ }^{a}$ Short- PAH exposure was evaluated by means of the urinary excretion of 1-hydroxypyrene. 1-hydroxypyrene levels were reported previously [43] ${ }^{b}$ Long-term PAH exposure was evaluated by means of anti-B[a]PDE-DNA adducts. Positive were workers with detectable adducts (> 1 adducts/10 ${ }^{8}$ nucleotides). Anti-B[a]PDE-DNA adduct levels were reported previously [43] 
Table 3 Predictors of SAA levels. Multiple linear regression analysis of influence of PAH exposure evaluated by urinary excretion of 1-hydroxypyrene, anti-B[a]PDE-DNA adduct levels in blood cells, GSTM1, CRP, smoking status and diet habits on serum SAA levels in coke oven workers $(n=87)$

\begin{tabular}{lllllll}
\hline & 1-hydroxypyrene & anti-B[a]PDE-DNA adducts & GSTM1 $^{\text {a }}$ & CRP & Smoking $^{\text {b }}$ & Diet $^{c}$ \\
\hline$\beta^{\text {d }}$ & 0.56 & -0.39 & -1.05 & 7.08 & -1.14 & 0.43 \\
$T^{d}$ & 2.20 & 0.86 & 1.61 & 14.5 & 1.88 & 0.70 \\
$p^{\text {-value }}{ }^{d}$ & $\mathbf{0 . 0 3 0}$ & 0.391 & 0.110 & $<\mathbf{0 . 0 0 0 1}$ & 0.063 & 0.487 \\
\hline
\end{tabular}

${ }^{a}$ GSTM1 genotypes was treated as dichotomous variables: GSTM1 $=1$ or 0 , Active or ${ }^{*} 0 /{ }^{*} 0$

${ }^{\mathrm{b}}$ Smoking $=1$ or 0 , current smokers or non-smokers

${ }^{\mathrm{c} D i e t}=1$ or 0 , charcoaled meat consumption more or less than once per week, respectively

${ }^{d}$ The $F$ test gave an $F$ of 38.6 and a $p$ value of $<0.0001$. $\beta$ is the slope. T is the test statistics $\beta /$ standard deviation of $\beta$

Bold font highlights statistically significant values

categories of 1-hydroxypyrene in urine, when tested by the Mann-Whitney $U$ test (Table 5), reflecting that the association to 1-hydroxypyrene is only seen when analysing by multiple linear regression simultaneously taking more explanatory variables into account.

SAA and CRP levels correlated closely $\left(R^{2}=0.74\right)$ and CRP had, as an explanatory variable of the SAA serum level, a multiple linear regression slope of 7. SAA and CRP blood levels have previously been shown to be closely associated in humans, e.g. in [59-61]. This shows that these two acute phase proteins to some extend are simultaneously regulated in the human inflammatory response. However, they exert different functions. CRP acts as a nonspecific opsonin to enhance phagocytosis [62] and SAA has important functions in especially modulation of HDL-mediated cholesterol transport [63]. During an acute phase response, SAA replaces Apo-A1 in HDL, and by this reverses the cholesterol flow, thereby promoting foam cell formation of peripheral macrophages and increased formation of atherosclerotic plaques $[11,18,19]$. Thus, although co-regulated, these two proteins have distinct roles in the acute phase response justifying that they are analysed separately for their involvement in diseases and mechanisms.

Concerning the time course of induction of the acute phase response, our results suggest that 1-hydroxypyrene was predictive of SAA, whereas anti-B[a]PDE-DNA adducts, a biomarker of long-term exposure, was not predictive of SAA levels. This is in agreement with the time course for induction of the acute phase responses in animal studies following airway exposure to carbon nanoparticles and diesel exhaust particles [23, 24, 64, 65]. Likewise, the GSTM1 null genotype has previously been shown to be a risk factor for anti-B[a]PDE-DNA adduct formation $[43,44]$ and was also not predictive of the SAA levels.

It can be discussed whether the effect of PAH on SAA is mediated by the particular fraction and its exposure to the lungs. Concerning the pathway of lung exposure, this is likely the most pronounced exposure pathway in coke oven workers. However, PAH can be also taken up over intact skin and in the gastrointestinal tract, and thus dermal and dietary exposure likely contributes to the $\mathrm{PAH}$ biomarker levels in blood and urine [44, 66-69] and these pathways likely contribute to the internal PAH dose in the coke oven workers. PAH is likely both present in the particulate phase and in the non-particulate gas phase and both PAH fractions contribute to the amount of inhaled PAH [70]. In a recent occupational exposure study among Polish coke oven workers, strong correlations between PAH levels in air (both pre- and post-shift) and urinary excretion of 1-hydroxypyrene [35]. Furthermore, the content of PAH in the particle phase correlates to total PAHs (gas and particle phase) when measured for a range of emission sources [36]; and, in chimney sweeps, PAH metabolites correlated positively with the percentage of soot sweeping suggesting that PAH markers were correlated to soot particles [37]. In addition, in animals, the acute phase response has been reported to be proportional with pulmonary

Table 4 Predictors of CRP levels. Multiple linear regression analysis of influence of PAH exposure evaluated by urinary excretion of 1hydroxypyrene, anti-B[a]PDE-DNA adduct levels in blood cells, GSTM1, SAA, smoking status and diet habits on serum CRP levels in coke oven workers $(n=87)$

\begin{tabular}{lllllll}
\hline & 1-hydroxypyrene & anti-B[a]PDE-DNA adducts & GSTM1 $^{\text {a }}$ & SAA & Smoking $^{\text {b }}$ & Diet $^{c}$ \\
\hline$\beta^{\text {d }}$ & -0.08 & 0.01 & 0.02 & 0.003 & 0.14 & -0.08 \\
$T^{d}$ & -2.51 & 0.26 & 0.21 & 12.92 & 1.83 & -0.94 \\
-value $^{d}$ & $\mathbf{0 . 0 1 4}$ & 0.793 & 0.834 & $<\mathbf{0 . 0 0 0 1}$ & 0.072 & 0.348 \\
\hline
\end{tabular}

${ }^{a}$ GSTM1 genotypes was treated as dichotomous variables: GSTM1 $=1$ or 0 , Active or ${ }^{*} 0 /{ }^{*} 0$

${ }^{\mathrm{b}}$ Smoking $=1$ or 0 , current smokers or non-smokers

${ }^{c}$ Diet $=1$ or 0 , charcoaled meat consumption more or less than once per week, respectively

${ }^{\mathrm{d}}$ The $\mathrm{F}$ test gave an $\mathrm{F}$ of 30.04 and a $p$ value of $<0.0001$. $\beta$ is the slope. $\mathrm{T}$ is the test statistics $\beta /$ standard deviation of $\beta$

Bold font highlights statistically significant values 
Table 5 Serum levels of SAA and CRP in relation to 1-hydroxypyrene urine levels

\begin{tabular}{llll}
\hline 1 -hydroxypyrene (umoles/mole creatinine) & $\mathrm{n}$ & SAA Median(range) & CRP Median(range) \\
\hline$I \leq 2.30$ & 29 & $1.87(0.62-34.6)$ & $0,42(0,04-24,3)$ \\
$\| I>2.30 \leq 7.04$ & 29 & $1,95(0,60-6,66)$ & $0,45(0,06-2.00)$ \\
$|I|>7.04$ & 29 & $1,67(0,79-34,6)$ & $0,33(0,08-8,51)$ \\
\hline
\end{tabular}

The serum levels of SAA and CRP were not significantly different inbetween the different ranges of 1-hydroxypyrene - when tested by the Mann-Whitney $U$ test

neutrophil influx and with total pulmonary deposited particle surface area [23, 71, 72]. Thus collectively these data suggest that the association between PAH and SAA reflect an association between particulate air pollution and SAA.

There is some evidence in the literature for the induction of the acute phase response of both $\mathrm{PAH}$ and of particles. In humans PAH exposure has been shown to be associated with serum CRP [21]. Biomonitoring studies having reported a correlation between occupational exposure to different types of particles and blood levels of acute phase proteins include the following exposures: Welding [73, 74], paper mill dust [75], emissions from firing of small weapons [76], and organic dust [53]. Increased blood levels of CRP has in some investigations been demonstrated in humans exposed to particulate matter [77-81]. In addition, animal studies have demonstrated that particles administered by intratracheal instillation and inhalation increase acute phase gene expression both at the mRNA and protein levels [24-32]. Thus these data are in line with the current findings suggesting that SAA is associated to PAH exposure and possibly associated to PAH in particles. Prolonged acute phase response induction has been linked to cardiovascular disease [10, 82-84], and there is evidence that both PAH and particulate air pollution have been associated with increased risk of cardiovascular disease in epidemiological studies $[7,8]$. In a recent study of chimney sweepers, associations between different urinary $\mathrm{PAH}$ metabolites and diastolic blood pressure were reported. In addition, chimney sweepers had increased blood levels of homocysteine, cholesterol, and high-density lipoprotein (HDL) as compared to the control group. The authors suggested that PAH is a driving force for developing cardiovascular disease [37]. Coke oven emissions have been reported to be a risk factor for hypertension and abnormal electrocardiograms in coke oven workers [85] and excess mortality has been observed in coke oven plant workers. Causes of this excess were cancer and cardiovascular diseases [86]. In light of this our data also add to the notion that there is an association between PAH and particle air pollution and increased risk of developing cardiovascular diseases.

\section{Conclusions}

Our data suggest that urinary 1-hydroxypyrene, as biomarker of short-term PAH exposure, and the serum level of CRP, predict the serum levels of SAA in coke oven workers; And thus that exposure of coke oven workers to $\mathrm{PAH}$ can lead to increased systemic acute response and potentially increased risk of cardiovascular disease.

\section{Additional files}

Additional file 1: Table S1. Predictors of SAA levels with CRP excluded from the analysis. Multiple linear regression analysis of influence of PAH exposure evaluated by urinary excretion of 1-hydroxypyrene, antiB[a]PDE-DNA adduct levels in blood cells, GSTM1, smoking status and diet habits on serum SAA levels in coke oven workers $(n=87)$. (DOCX 14 $\mathrm{kb})$

Additional file 2: Table S2. Predictors of CRP levels with SAA excluded from the analysis. Multiple linear regression analysis of influence of PAH exposure evaluated by urinary excretion of 1-hydroxypyrene, antiB[a]PDE-DNA adduct levels in blood cells, GSTM1, smoking status and diet habits on serum CRP levels in coke oven workers $(n=87)$. (DOCX 14 $\mathrm{kb})$

\section{Abbreviations}

Anti-B[a]PDE)-DNA: Anti-benzo[a]pyrene diolepoxide; BEl: Biological exposure index; CRP: C-reactive protein; CTPV: Coal tar pitch volatiles;

CYP450: Cytochrome P450; ELISA: Enzyme-linked Immunosorbent assay;

GSTM1: Glutathione S-transferase Mu 1; HPLC: High performance liquid chromatography; LMF: Mononuclear lymphocyte plus monocyte fractions; LOD: Level of detection; PAH: Polycyclic aromatic hydrocarbons;

PCR: Polymerase chain reaction; RR: Relative risk; SAA: Serum amyloid A; TLV: Threshold limit value

\section{Acknowledgements}

Ulla Tegner is thanked for excellent technical assistance

\section{Authors' contributions}

$\mathrm{NH}$ interpreted the results, and wrote the manuscript. DM organised the research in Poland, wrote the application and obtained the consent of the Bioethics Committee for carrying out the research. In addition DM reviewed and corrected the manuscript. AK organised the collection of biological samples and the questionnaire research. In addition DM supervised the appropriate storage and shipment of biological samples. MC performed laboratory analysis. SP conceived the study, interpreted the results and wrote the manuscript. UV conceived the study, interpreted the results and wrote the manuscript. All authors read and approved the final manuscript.

\section{Funding}

The project was financially supported by Danish Centre for Nanosafety II.

\section{Availability of data and materials}

The datasets used and/or analysed during the current study are available from the corresponding author on reasonable request.

\section{Ethics approval and consent to participate}

All participants gave their informed consent. All information regarding participants was rendered anonymous after collection of data, urine and blood samples. The study was reviewed and approved by the appropriate Ethics Committee of the Institute of Occupational Medicine and 
Environmental Health in Sosnowiec (Poland). Agreement No. 20 published in December 2001

\section{Consent for publication}

Not applicable.

\section{Competing interests}

The authors declare that they have no competing interests.

\section{Author details}

${ }^{1}$ National Research Centre for the Working Environment, DK-2100 Copenhagen, Denmark. ${ }^{2}$ Institute of Occupational Medicine and Environmental Health, Sosnowiec, Poland. ${ }^{3}$ Witold Pilecki State School of Higher Education, Nursing Institute, Oświęcim, Poland. ${ }^{4}$ Department of Cardiac, Thoracic and Vascular Sciences, University of Padova, Padova, Italy.

\section{Received: 12 March 2019 Accepted: 23 August 2019} Published online: 02 September 2019

\section{References}

1. IARC. Outdoor air pollution. WHO; 2016. 1-454. Available from: https:// monographs.iarc.fr/wp-content/uploads/2018/06/mono109.pdf

2. Franklin BA, Brook R, Arden PC. Air pollution and cardiovascular disease. Curr Probl Cardiol. 2015;40:207-38 Available from: http://www.ncbi.nlm.nih. gov/pubmed/25882781.

3. Alshaarawy $\mathrm{O}$, Elbaz HA, Andrew ME. The association of urinary polycyclic aromatic hydrocarbon biomarkers and cardiovascular disease in the US population. Environ Int. 2016;89-90:174-8 Available from: http://www.ncbi. nlm.nih.gov/pubmed/26878282.

4. Xu X, Cook RL, llacqua VA, Kan H, Talbott EO, Kearney G. Studying associations between urinary metabolites of polycyclic aromatic hydrocarbons (PAHs) and cardiovascular diseases in the United States. Sci Total Environ. 2010;408:4943-8 Available from: http://www.ncbi.nlm.nih.gov/ pubmed/20701951.

5. Xu X, Hu H, Kearney GD, Kan H, Sheps DS. Studying the effects of polycyclic aromatic hydrocarbons on peripheral arterial disease in the United States. Sci Total Environ. 2013:461-462:341-7 Available from: http://www.ncbi.nlm. nih.gov/pubmed/23747551.

6. Brucker N, Charão MF, Moro AM, Ferrari P, Bubols G, Sauer E, et al. Atherosclerotic process in taxi drivers occupationally exposed to air pollution and co-morbidities. Environ Res. 2014;131:31-8 Cited 2019 Feb 28; Available from: https://linkinghub.elsevier.com/retrieve/pii/S0013935114000395.

7. Weichenthal S. Selected physiological effects of ultrafine particles in acute cardiovascular morbidity. Environ Res. 2012;115:26-36 Available from: http:// www.ncbi.nlm.nih.gov/pubmed/22465230

8. Miller MR, Shaw CA, Langrish JP. From particles to patients: oxidative stress and the cardiovascular effects of air pollution. Future Cardiol. 2012;8:577602 Available from: http://www.ncbi.nlm.nih.gov/pubmed/22871197.

9. Torén K, Bergdahl IA, Nilsson T, Järvholm B. Occupational exposure to particulate air pollution and mortality due to ischaemic heart disease and cerebrovascular disease. Occup Environ Med. 2007;64:515-9 Available from: http://www.ncbi.nlm.nih.gov/pubmed/17303673.

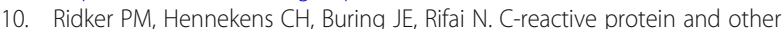
markers of inflammation in the prediction of cardiovascular disease in women. N Engl J Med. 2000;342:836-43 Available from: http://www.ncbi. nlm.nih.gov/pubmed/10733371.

11. Lee HY, Kim SD, Baek S-H, Choi JH, Cho K-H, Zabel BA, et al. Serum amyloid A stimulates macrophage foam cell formation via lectin-like oxidized lowdensity lipoprotein receptor 1 upregulation. Biochem Biophys Res Commun. 2013;433:18-23 Available from: http://www.ncbi.nlm.nih.gov/ pubmed/23454129.

12. Lee HY, Kim SD, Baek S-H, Choi JH, Bae Y-S. Role of formyl peptide receptor 2 on the serum amyloid A-induced macrophage foam cell formation. Biochem Biophys Res Commun. 2013:433:255-9 Available from: http://www. ncbi.nlm.nih.gov/pubmed/23500463.

13. Ray BK, Ray A. Involvement of an SAF-like transcription Factor in the activation of serum amyloid a gene in Monocyte/Macrophage cells by Lipopolysaccharide †. Biochemistry. 1997:36:4662-8 Cited 2019 Mar 5; Available from: http://www.ncbi.nlm.nih.gov/pubmed/9109677.

14. Lusis AJ, Navab M. Lipoprotein oxidation and gene expression in the artery wall. New opportunities for pharmacologic intervention in atherosclerosis.
Biochem Pharmacol. 1993;46:2119-26 Cited 2019 Mar 5; Available from: http://www.ncbi.nlm.nih.gov/pubmed/8274144.

15. Liao F, Andalibi A, deBeer FC, Fogelman AM, Lusis AJ. Genetic control of inflammatory gene induction and NF-kappa B-like transcription factor activation in response to an atherogenic diet in mice. J Clin Invest. 1993;91: 2572-9 Cited 2019 Mar 5; Available from: http://www.ncbi.nlm.nih.gov/ pubmed/8514869.

16. Meek RL, Urieli-Shoval S, Benditt EP. Expression of apolipoprotein serum amyloid A mRNA in human atherosclerotic lesions and cultured vascular cells: implications for serum amyloid A function. Proc Natl Acad Sci U S A. 1994;91:3186-90 Cited 2019 Mar 5; Available from: http://www.ncbi.nlm.nih. gov/pubmed/8159722.

17. Krishack PA, Bhanvadia CV, Lukens J, Sontag TJ, De Beer MC, Getz GS, et al. Serum Amyloid A facilitates early lesion development in Ldlr-/- mice. J Am Heart Assoc. 2015;4 Available from: http://www.ncbi.nlm.nih.gov/ pubmed/26187995.

18. Thompson JC, Wilson PG, Shridas P, Ji A, de Beer M, de Beer FC, et al. Serum amyloid A3 is pro-atherogenic. Atherosclerosis. 2018;268:32-5 Available from: http://www.ncbi.nlm.nih.gov/pubmed/29175652.

19. Dong Z, Wu T, Qin W, An C, Wang Z, Zhang M, et al. Serum amyloid A directly accelerates the progression of atherosclerosis in apolipoprotein Edeficient mice. Mol Med. 2011;17:1357-64 Available from: http://www.ncbi. nlm.nih.gov/pubmed/21953420.

20. Pai JK, Mukamal K, Rexrode KM, Rimm EB. C-reactive protein (CRP) gene polymorphisms, CRP levels, and risk of incident coronary heart disease in two nested case-control studies. PLoS One. 2008:3:e1395 Cited 2019 Mar 5; Kronenberg F, editor. Available from: https://dx.plos.org/10.1371/journal. pone.0001395.

21. Alshaarawy O, Zhu M, Ducatman A, Conway B, Andrew ME. Polycyclic aromatic hydrocarbon biomarkers and serum markers of inflammation. $A$ positive association that is more evident in men. Environ Res. 2013;126:98104 Cited 2019 Feb 28; Available from: https://linkinghub.elsevier.com/ retrieve/pii/S0013935113001229.

22. Stone V, Miller MR, Clift MJD, Elder A, Mills NL, Møller $\mathrm{P}$, et al. Nanomaterials versus ambient ultrafine particles: An opportunity to exchange toxicology knowledge. Environ Health Perspect. 2017;125:106002 Available from: http:// www.ncbi.nlm.nih.gov/pubmed/29017987.

23. Saber AT, Jacobsen NR, Jackson P, Poulsen SS, Kyjovska ZO, Halappanavar S, et al. Particle-induced pulmonary acute phase response may be the causal link between particle inhalation and cardiovascular disease. WileyInterdiscipRevNanomedNanobiotechnol, vol. 6. Copenhagen: National Research Centre for the Working Environment; 2014. p. 517-31.

24. Poulsen SS, Knudsen KB, Jackson P, Weydahl IEK, Saber AT, Wallin H, et al. Multi-walled carbon nanotube-physicochemical properties predict the systemic acute phase response following pulmonary exposure in mice. PLoS One. 2017;12:e0174167 Available from: http://www.ncbi.nlm.nih.gov/ pubmed/28380028.

25. Saber AT, Lamson JS, Jacobsen NR, Ravn-Haren G, Hougaard KS, Nyendi AN, et al. Particle-induced pulmonary acute phase response correlates with neutrophil influx linking inhaled particles and cardiovascular risk. PLoS One. 2013;8:e69020 The National Research Centre for the Working Environment, Copenhagen, Denmark. ats@nrcwe.dk.

26. Bengtson S, Knudsen KB, Kyjovska ZO, Berthing T, Skaug V, Levin M, et al. Differences in inflammation and acute phase response but similar genotoxicity in mice following pulmonary exposure to graphene oxide and reduced graphene oxide. PLoS One. 2017;12:e0178355 National Research Centre for the Working Environment, Copenhagen O, Denmark Department of Science and Environment, Roskilde University, Roskilde, Denmark National Research Centre for the Working Environment, Copenhagen O, Denmark National Research Centre.

27. Kyjovska ZO, Jacobsen NR, Saber AT, Bengtson S, Jackson P, Wallin H, et al. DNA damage following pulmonary exposure by instillation to low doses of carbon black (Printex 90) nanoparticles in mice. Environ Mol Mutagen. 2015; 56:41-9 Danish Centre for Nanosafety, National Research Centre for the working environment, Copenhagen O, Denmark.

28. Halappanavar S, Jackson P, Williams A, Jensen KA, Hougaard KS, Vogel U, et al. Pulmonary response to surface-coated nanotitanium dioxide particles includes induction of acute phase response genes, inflammatory cascades, and changes in microRNAs: a toxicogenomic study. Environ Mol Mutagen. 2011:52:425-39 Environmental Health Science and Research Bureau, Health Canada, Ottawa, Ontario, Canada. sabina.halappanavar@hc-sc.gc.ca. 
29. Kang GS, Gillespie PA, Chen LC. Inhalation exposure to nickel hydroxide nanoparticles induces systemic acute phase response in mice. Toxicol Res. 2011;27:19-23 Department of Environmental Medicine, New York University School of Medicine, 57 Old Forge Road, Tuxedo, NY 10987, USA.

30. Park EJ, Kim H, Kim Y, Yi J, Choi K, Park K. Inflammatory responses may be induced by a single intratracheal instillation of iron nanoparticles in mice. Toxicology. 2010;275:65-71 College of Pharmacy, Dongduk Women's University, 23-1, Wolgok-dong, Seongbuk-gu, Seoul 136-714, Republic of Korea.

31. Higashisaka K, Yoshioka Y, Yamashita K, Morishita Y, Fujimura M, Nabeshi H, et al. Acute phase proteins as biomarkers for predicting the exposure and toxicity of nanomaterials. Biomaterials. 2011;32:3-9 Available from: http:// www.ncbi.nlm.nih.gov/pubmed/20864168

32. Li R, Navab M, Pakbin P, Ning Z, Navab K, Hough G, et al. Ambient ultrafine particles alter lipid metabolism and HDL anti-oxidant capacity in LDLR-null mice. J Lipid Res. 2013;54:1608-15 Available from: http://www.ncbi.nlm.nih. gov/pubmed/23564731.

33. Monsé $\mathrm{C}$, Hagemeyer $\mathrm{O}$, Raulf $\mathrm{M}$, Jettkant $\mathrm{B}$, van Kampen $\mathrm{V}$, Kendzia $\mathrm{B}$, et al. Concentration-dependent systemic response after inhalation of nano-sized zinc oxide particles in human volunteers. Part Fibre Toxicol. 2018;15:8 Available from: http://www.ncbi.nlm.nih.gov/pubmed/29429408.

34. Vogel U, Cassee FR. Editorial: dose-dependent ZnO particle-induced acute phase response in humans warrants re-evaluation of occupational exposure limits for metal oxides. Part Fibre Toxicol. 2018;15:7 Available from: http:// www.ncbi.nlm.nih.gov/pubmed/29429406.

35. Zając J, Gomółka E, Maziarz B, Szot W. Occupational exposure to Polycyclic Aromatic Hydrocarbons in polish coke plant workers. Ann Occup Hyg. 2016; 60:1062-71 Available from: http://www.ncbi.nlm.nih.gov/pubmed/27621218.

36. Samburova V, Zielinska B, Khlystov A. Do 16 Polycyclic Aromatic Hydrocarbons Represent PAH Air Toxicity? Toxics. 2017;5:17 Cited 2018 Aug 23; Available from: http://www.ncbi.nlm.nih.gov/pubmed/29051449.

37. Alhamdow A, Lindh C, Albin M, Gustavsson P, Tinnerberg H, Broberg K. Early markers of cardiovascular disease are associated with occupational exposure to polycyclic aromatic hydrocarbons. Sci Rep. 2017;7:9426 Cited 2018 Aug 23; Available from: http://www.ncbi.n/m.nih.gov/pubmed/28842704.

38. Jongeneelen FJ. Biological exposure limit for occupational exposure to coal tar pitch volatiles at cokeovens. Int Arch Occup Environ Health. 1992;63: 511-6 Available from: http://www.ncbi.n/m.nih.gov/pubmed/1587624.

39. Jongeneelen FJ. A guidance value of 1-hydroxypyrene in urine in view of acceptable occupational exposure to polycyclic aromatic hydrocarbons. Toxicol Lett. 2014;231:239-48 Available from: http://www.ncbi.nIm.nih.gov/ pubmed/24831967.

40. Andersen MHG, Saber AT, Pedersen JE, Pedersen PB, Clausen PA, Løhr M, et al. Assessment of polycyclic aromatic hydrocarbon exposure, lung function, systemic inflammation, and genotoxicity in peripheral blood mononuclear cells from firefighters before and after a work shift. Environ Mol Mutagen. 2018;59:539-48 Available from: http://www.ncbi.nlm.nih.gov/pubmed/29761 929.

41. Andersen MHG, Saber AT, Clausen PA, Pedersen JE, Løhr M, Kermanizadeh A, et al. Association between polycyclic aromatic hydrocarbon exposure and peripheral blood mononuclear cell DNA damage in human volunteers during fire extinction exercises. Mutagenesis. 2018;33:105-15 Available from: http://www.ncbi.nlm.nih.gov/pubmed/29045708.

42. Keir JLA, Akhtar US, Matschke DMJ, Kirkham TL, Chan HM, Ayotte $P$, et al Elevated Exposures to Polycyclic Aromatic Hydrocarbons and Other Organic Mutagens in Ottawa Firefighters Participating in Emergency, On-Shift Fire Suppression. Environ Sci Technol. 2017;51:12745-55 Available from: http:// pubs.acs.org/doi/10.1021/acs.est.7b02850.

43. Pavanello S, Siwinska E, Mielzynska D, Clonfero E. GSTM1 null genotype as a risk factor for anti-BPDE-DNA adduct formation in mononuclear white blood cells of coke-oven workers. Mutat Res. 2004;558:53-62 Available from: http://www.ncbi.nlm.nih.gov/pubmed/15036119.

44. Pavanello S, Gabbani G, Mastrangelo G, Brugnone F, Maccacaro G, Clonfero E. Influence of GSTM1 genotypes on anti-BPDE-DNA adduct levels in mononuclear white blood cells of humans exposed to PAH. Int Arch Occup Environ Health. 1999;72:238-46 Available from: http://www.ncbi.nlm.nih. gov/pubmed/10491778.

45. Jylhävä J, Haarala A, Eklund C, Pertovaara M, Kähönen M, Hutri-Kähönen N, et al. Serum amyloid A is independently associated with metabolic risk factors but not with early atherosclerosis: the cardiovascular risk in young Finns Study. J Intern Med. 2009;266:286-95 Available from: http://www.ncbi. nlm.nih.gov/pubmed/19702793.
46. Pavanello S, Pulliero A, Siwinska E, Mielzynska D, Clonfero E. Reduced nucleotide excision repair and GSTM1-null genotypes influence antiB[a]PDE-DNA adduct levels in mononuclear white blood cells of highly PAH-exposed coke oven workers. Carcinogenesis. 2005;26:169-75 Available from: http://www.ncbi.nlm.nih.gov/pubmed/15471894.

47. Clonfero E, Granella M, Marchioro M, Barra EL, Nardini B, Ferri G, et al. Urinary excretion of mutagens in coke oven workers. Carcinogenesis. 1995; 16:547-54 Available from: http://www.ncbi.n/m.nih.gov/pubmed/7697812.

48. Jongeneelen FJ. Methods for routine biological monitoring of carcinogenic PAH-mixtures. Sci Total Environ. 1997;199:141-9 Available from: http://www. ncbi.nlm.nih.gov/pubmed/9200857.

49. ACGIH. TLVs and BEls. ACGIH Publications, 2003.

50. Pavanello S, Favretto D, Brugnone F, Mastrangelo G, Dal Pra G, Clonfero E. HPLC/fluorescence determination of anti-BPDE-DNA adducts in mononuclear white blood cells from PAH-exposed humans. Carcinogenesis. 1999;20:431-5 Available from: http://www.ncbi.nlm.nih. gov/pubmed/10190558.

51. Alexandrov K, Rojas M, Geneste O, Castegnaro M, Camus AM, Petruzzelli S, et al. An improved fluorometric assay for dosimetry of benzo(a)pyrene diolepoxide-DNA adducts in smokers' lung: comparisons with total bulky adducts and aryl hydrocarbon hydroxylase activity. Cancer Res. 1992;52: 6248-53 Available from: http://www.ncbi.nlm.nih.gov/pubmed/1423269.

52. Pavanello S, Simioli P, Lupi S, Gregorio P, Clonfero E. Exposure levels and cytochrome P450 1A2 activity, but not N-acetyltransferase, glutathione Stransferase (GST) M1 and T1, influence urinary mutagen excretion in smokers. Cancer Epidemiol Biomarkers Prev. 2002;11:998-1003 Available from: http://www.ncbi.nlm.nih.gov/pubmed/12376499.

53. Madsen AM, Thilsing T, Bælum J, Garde AH, Vogel U. Occupational exposure levels of bioaerosol components are associated with serum levels of the acute phase protein Serum Amyloid A in greenhouse workers. Environ Health. 2016;15:9 Available from: http://www.ncbi.nlm. nih.gov/pubmed/26792395.

54. Dixon WJ. BMDP statistical software manual. Berkeley: University of California Press; 1992.

55. ACGIH. 2016 TLVs and BEls. 2016. Available from: https://www.acgih.org/ forms/store/ProductFormPublic/2016-tlvs-and-beis

56. Buchet JP, Ferreira M, Burrion JB, Leroy T, Kirsch-Volders M, Van Hummelen $P$, et al. Tumor markers in serum, polyamines and modified nucleosides in urine, and cytogenetic aberrations in lymphocytes of workers exposed to polycyclic aromatic hydrocarbons. Am J Ind Med. 1995;27:523-43 Cited 2018 Sep 12; Available from: http://www.ncbi.nlm.nih.gov/pubmed/7793423.

57. Yang R-Z, Lee M-J, Hu H, Pollin TI, Ryan AS, Nicklas BJ, et al. Acute-phase serum Amyloid A: an inflammatory adipokine and potential link between obesity and its metabolic complications. PLoS Med. 2006;3:e287 Lazar M, editor. Cited 2018 Sep 10; Available from: http://www.ncbi.nlm.nih.gov/ pubmed/16737350.

58. Lappalainen $\mathrm{T}$, Kolehmainen $\mathrm{M}$, Schwab U, Pulkkinen L, Laaksonen DE, Rauramaa $\mathrm{R}$, et al. Serum concentrations and expressions of serum amyloid A and leptin in adipose tissue are interrelated: the Genobin Study. Eur J Endocrinol. 2008;158:333-41 Cited 2018 Sep 10; Available from: https://eje. bioscientifica.com/view/journals/eje/158/3/333.xml.

59. Ko Y-L, Hsu L-A, Wu S, Teng M-S, Chou H-H. CRP and SAA1 Haplotypes Are Associated with Both C-Reactive Protein and Serum Amyloid A Levels: Role of Suppression Effects. Mediators Inflamm. 2016;2016:5830361 Available from: http://www.ncbi.nlm.nih.gov/pubmed/27313400.

60. Ardila CM, Guzmán IC. Comparison of serum amyloid A protein and Creactive protein levels as inflammatory markers in periodontitis. J Periodontal Implant Sci. 2015;45:14-22 Available from: http://www.ncbi.nIm. nih.gov/pubmed/25722922.

61. Overgaard AJ, McGuire JN, Hovind P, Parving $H-H$, Rossing P, Pociot F. Serum amyloid $A$ and $C$-reactive protein levels may predict microalbuminuria and macroalbuminuria in newly diagnosed type 1 diabetic patients. J Diabetes Complications. 2013;27:59-63 Available from: http://www.ncbi.n/m.nih.gov/pubmed/22885250.

62. Sproston NR, Ashworth JJ. Role of C-reactive protein at sites of inflammation and infection. Front Immunol. 2018;9:754 Available from: http://www.ncbi.nlm.nih.gov/pubmed/29706967.

63. Sack GH. Serum amyloid A - a review. Mol Med. 2018;24:46 Available from: http://www.ncbi.nlm.nih.gov/pubmed/30165816.

64. Bourdon JA, Saber AT, Jacobsen NR, Jensen KA, Madsen AM, Lamson JS, et al. Carbon black nanoparticle instillation induces sustained inflammation 
and genotoxicity in mouse lung and liver. Part FibreToxicol. 2012;9:5 Health Canada, Environmental and Radiation Health Sciences Directorate, Mechanistic Studies Division, Tunney's Pasture, Ottawa, Canada.

65. Kyjovska ZO, Jacobsen NR, Saber AT, Bengtson S, Jackson P, Wallin H, et al. DNA strand breaks, acute phase response and inflammation following pulmonary exposure by instillation to the diesel exhaust particle NIST1650b in mice. Mutagenesis. 2015;30:499-507 National Research Centre for the Working Environment, Lerso Parkalle 105, DK-2100 Copenhagen O, Denmark National Research Centre for the Working Environment, Lerso Parkalle 105, DK-2100 Copenhagen O, Denmark National Research Centre for the Working Enviro.

66. Andersen MHG, Saber AT, Clausen PA, Pedersen JE, Løhr M, Kermanizadeh $A$, et al. Association between polycyclic aromatic hydrocarbon exposure and peripheral blood mononuclear cell DNA damage in human volunteers during fire extinction exercises. Mutagenesis. 2018;33:105-15 Available from: https://academic.oup.com/mutage/article/33/1/105/4553087.

67. Mastrangelo G, Veller Fornasa C, Pavanello S, Mercer G, Lazzaro M, Milan G, et al. Polyaromatic hydrocarbons administered in humans by dermal route increase total IgE. Int J Immunopathol Pharmacol. 2003;16:145-50 Available from: http://www.ncbi.n/m.nih.gov/pubmed/12797905.

68. Pavanello S, Pulliero A, Saia BO, Clonfero E. Determinants of antibenzo[a]pyrene diol epoxide-DNA adduct formation in lymphomonocytes of the general population. Mutat Res. 2006;611:54-63 Available from: http:// www.ncbi.nlm.nih.gov/pubmed/16978913.

69. VanRooij JGM, De Roos JHC, Bodelier-Bade MM, Jongeneelen FJ. Absorption of polycyclic aromatic hydrocarbons through human skin: differences between anatomical sites and individuals. J Toxicol Environ Health. 1993;38: 355-68 Available from: http://www.tandfonline.com/doi/abs/10.1080/152 87399309531724.

70. Atkinson R, Arey J. Atmospheric chemistry of gas-phase polycyclic aromatic hydrocarbons: formation of atmospheric mutagens. Environ Health Perspect. 1994;102(Suppl 4):117-26 Cited 2018 Aug 23; Available from: http://www. ncbi.nlm.nih.gov/pubmed/7821285.

71. Poulsen SS, Jackson P, Kling K, Knudsen KB, Skaug V, Kyjovska ZO, et al. Multi-walled carbon nanotube physicochemical properties predict pulmonary inflammation and genotoxicity. Nanotoxicology. 2016;10:126375 A National Research Centre for the Working Environment, Copenhagen $\mathrm{O}$, Denmark a National Research Centre for the Working Environment, Copenhagen O , Denmark a National Research Centre for the Working Environment, Copenhagen O, Denmark a National Res.

72. Poulsen SS, Saber AT, Williams A, Andersen O, Kobler C, Atluri R, et al. MWCNTs of different physicochemical properties cause similar inflammatory responses, but differences in transcriptional and histological markers of fibrosis in mouse lungs. Toxicol Appl Pharmacol. 2015;284:16-32 National Research Centre for the Working Environment, Copenhagen DK-2100, Denmark; Department of Science, Systems and Models, Roskilde University, DK-4000 Roskilde, Denmark. Electronic address: spo@nrcwe.dk National Research Centre for the Working Environ.

73. Baumann R, Gube M, Markert A, Davatgarbenam S, Kossack V, Gerhards B, et al. Systemic serum amyloid $A$ as a biomarker for exposure to zinc and/or copper-containing metal fumes. J Expo Sci Environ Epidemiol. 2017; Available from: http://www.ncbi.nlm.nih.gov/pubmed/28176762.

74. Li H, Hedmer M, Kåredal M, Björk J, Stockfelt L, Tinnerberg H, et al. A crosssectional study of the cardiovascular effects of welding fumes. PLoS One. 2015;10:e0131648 Available from: http://www.ncbi.nlm.nih.gov/ pubmed/26147298.

75. Westberg $H$, Elihn $K$, Andersson E, Persson B, Andersson L, Bryngelsson $\mathrm{I}-\mathrm{L}$, et al. Inflammatory markers and exposure to airborne particles among workers in a Swedish pulp and paper mill. Int Arch Occup Environ Health. 2016;89:813-22 Available from: http://link.springer.com/1 0.1007/s00420-016-1119-5.

76. Sikkeland LIB, Borander AK, Voie $\varnothing A$, Aass HCD, Øvstebø R, Aukrust $P$, et al. Systemic and Airway Inflammation After Exposure to Fumes from Military Small Arms. Am J Respir Crit Care Med. 2017; Available from: http://www. ncbi.nlm.nih.gov/pubmed/29144885.

77. Donaldson K, Stone V, Seaton A, MacNee W. Ambient particle inhalation and the cardiovascular system: potential mechanisms. Environ Health Perspect. 2001;109(Suppl):523-7 Available from: http://www.ncbi.nlm.nih. gov/pubmed/11544157.

78. Pope CA, Hansen ML, Long RW, Nielsen KR, Eatough NL, Wilson WE, et al. Ambient particulate air pollution, heart rate variability, and blood markers of inflammation in a panel of elderly subjects. Environ Health Perspect. 2004; 112:339-45 Available from: http://www.ncbi.nlm.nih.gov/pubmed/14998750.

79. Riediker M, Cascio WE, Griggs TR, Herbst MC, Bromberg PA, Neas L, et al. Particulate matter exposure in cars is associated with cardiovascular effects in healthy young men. Am J Respir Crit Care Med. 2004;169:934-40 Available from: http://www.ncbi.nlm.nih.gov/pubmed/14962820.

80. Rückerl R, Ibald-Mulli A, Koenig W, Schneider A, Woelke G, Cyrys J, et al. Air pollution and markers of inflammation and coagulation in patients with coronary heart disease. Am J Respir Crit Care Med. 2006;173:432-41 Available from: http://www.ncbi.nlm.nih.gov/pubmed/16293802.

81. Zhang Z, Chang L-Y, Lau AKH, Chan T-C, Chieh Chuang Y, Chan J, et al. Satellite-based estimates of long-term exposure to fine particulate matter are associated with C-reactive protein in 30034 Taiwanese adults. Int J Epidemiol. 2017;46:1126-36 Available from: http://www.ncbi.nlm.nih.gov/ pubmed/28541501.

82. Albert MA, Ridker PM. The role of C-reactive protein in cardiovascular disease risk. Curr Cardiol Rep. 1999;1:99-104 Available from: http://www. ncbi.nlm.nih.gov/pubmed/10980827.

83. Lowe GD. The relationship between infection, inflammation, and cardiovascular disease: an overview. Ann Periodontol. 2001;6:1-8 Available from: http://www.ncbi.nlm.nih.gov/pubmed/11887452.

84. Mezaki T, Matsubara T, Hori T, Higuchi K, Nakamura A, Nakagawa I, et al. Plasma levels of soluble thrombomodulin, C-reactive protein, and serum amyloid A protein in the atherosclerotic coronary circulation. Jpn Heart J. 2003;44:601-12 Available from: http://www.ncbi.nlm.nih.gov/ pubmed/14587642.

85. Yang K, Jiang X, Cheng S, Chen C, Cao X, Tu B. Effects of coke oven emissions and benzo[a]pyrene on blood pressure and electrocardiogram in coke oven workers. J Occup Health. 2017;59:1-7 Available from: http://www. ncbi.nlm.nih.gov/pubmed/27885241.

86. Chau N, Bertrand JP, Mur JM, Figueredo A, Patris A, Moulin JJ, et al. Mortality in retired coke oven plant workers. Br J Ind Med. 1993;50:127-35 Available from: http://www.ncbi.nlm.nih.gov/pubmed/8435345.

\section{Publisher's Note}

Springer Nature remains neutral with regard to jurisdictional claims in published maps and institutional affiliations.

\section{Ready to submit your research? Choose BMC and benefit from:}

- fast, convenient online submission

- thorough peer review by experienced researchers in your field

- rapid publication on acceptance

- support for research data, including large and complex data types

- gold Open Access which fosters wider collaboration and increased citations

- maximum visibility for your research: over $100 \mathrm{M}$ website views per year

At BMC, research is always in progress.

Learn more biomedcentral.com/submissions 